Submitted 30.03.2016. Approved 14.06.2016

Evaluated by double blind review process

Scientific Editor: Maria Silene Leite

DOI: http:///dx.doi/10.12660/joscmv9n1p110-128

\title{
Social Interaction and Price Transmission in Multi-Tier Food Supply Chains
}

\author{
Maria Widyarini \\ Professor at Parahyangan Catholic University - Bandung - West Java, Indonesia \\ signati.bdg@gmail.com \\ Togar M Simatupang \\ Professor at Bandung Institute of Technology, School of Business and Management - West Java, Indonesia \\ togar@sbm-itb.ac.id \\ Per Engelseth \\ Professor at Molde University College - Molde, Norway \\ per.engelseth@himolde.no
}

\begin{abstract}
This research focuses on social interaction associated with price transmission in a multitier rice supply chain. A case study and qualitative methods are employed to examine a well-established supply network in Karawang District in Indonesia. Farmers and traders used their existing network in selling rice crops to traders and adopted a payment scheme for cash-and-carry transactions. Information on the market situation was obtained through personal interviews and observations including text messaging with farmer and trader informants. Evidence reveals that social relationships are vital in transmitting price information among networked actors to maintain the flow of rice, mitigate risk, and avoid losses due to poor quality of the rice product. Findings show that social interaction enables actors in an end-to-end rice supply chain to deal with the assurance of supply rationing.
\end{abstract}

Keywords: Social interaction, price transmission, pricing, information seeking, supply chain. 


\section{INTRODUCTION}

Price transmission of goods, such as rice, in networks is dependent on common network structures. Although there is variation in complexity, price transmission always involves sequentially interdependent stages of transformation (Alderson, 1965; Thompson, 1967). The supply network of such goodsis impacted by trading, and the price transmission is an inherent component in trading goods and services. In the food industry, paying attention to this end-to-end food supply has become pertinent in recent years. The traceability requirements of food products entail a need to inform about product safety and quality features, including all transformations from harvest or fishing (Engelseth, 2009, 2012). Managing the flow of goods and services plays a key role during aproduction involving product transformation. The aim of a production is to achieve customer value, which is vital in supply chain management (SCM) because it is ultimately associated with end-user perceptions. Value, in this perspective, is associated with benefit perceptions weighed against sacrifices, and it is negotiated through the chain of information and communication (Engelseth, 2016). Price is a vital component in this negotiation. Being negotiable, price is not a fixed metric. Research about the supply network in this study is intended to provide an empirical understanding that rice pricing furthers our knowledge of the SCM of food supply.

The first stream of research associated with price transmissionis concerned with the price transmission phenomena in which the negotiation of price associated with customer value is considered as a perception. Research about price transmission along a food chain was conducted by Vavra and Goodwin (2005) who analyzed the vertical price relationships which were characterized by the magnitude, speed and nature of the adjustments of an abrupt "shock" change in prices at one level and in the up- or downstream prices along the food chain. Jensen and Moller (2007) studied price transmission in the Danish food chain, including its vertical price interaction characterized by the degree of completeness of pass-through, speed and type of price adjustments through the supply chain. Their discussion about the vertical price transmission involved the creation of a single set of measures to define the speed, direction and magnitude of the impacts of price adjustments. The results of the study showed that there were few social interaction phenomena among the actors in the supply chain (Jensen \& Moller, 2007; Vavra \& Goodwin, 2005).

The second stream on price transmission deals with the underlying factors that help explain price transmission. Aramyan and Kuiper (2009) stated that factors explaining price transmission were market power, adjustment costs, public interventions, publicity/food scares, and perishability of the products. Bunte (2006) argued that price transmission addressed the imperfect price transmission corresponding to the market power in the agri-food chains. Little explanation has been provided about social interactions among the actors during the price transmission in the agri-food supply chains. Previous research treats social interactions as an exogenous factor in price transmission.

Price transmission in agri-food supply chains is an essential component of trading in a supply chain, an exchange process that involves income distribution among the supply chain actors (Bunte, 2006). During the price transmission, there is social interaction which is understood to play an important role in shaping the price. Thus, this study attempts to describe and investigate the social interaction phenomena of the price transmission along the rice supply chain. Friedman (1980) stated the role of prices in an organized economic activity is to transmit information, to provide an incentive to react to the information and to determine income distribution. These three functions are closely interrelated to social interactions. In addition, by adopting a transvection model of Alderson (1965), the role of price transmission is viewed rom the end-to-end food supply perspective. The transvection model has since been expanded by taking into consideration the interdependency theory (see Engelseth, 2016; Hammervoll, 2014; Thompson, 1967).

Taking the Aldersonian transvection perspective of goods supply, Engelseth and Felzensztein (2012) focused on "transformation" and end-user utility concerns. Production creates "service" that has values (Penrose, 1959). A bundling of goods and intangible deliverables are perceived and valued by the customer (Vargo \& Lusch, 2004). Thompson (1967) studied the provision of service taking place in the supply network context by considering rice pricing which involves both interdependent human social interactions and negotiation processes, or called "mutual adjustment". Further, Orton and Weick(1990) studied the trading in an end-to-end supply chain structure, involving a long-linked 
technology. Such trading creates reciprocal interdependencies in a marketing channel, consisting of a series of intermediaries trading. This is in line with Engelseth's argument that said that commodity-like food supplies need to be flowed through a seriesof markets (Engelseth, 2016).

This case study, conducted in Karawang District of West Java, seeks to describe the practice of rice pricing in a supply chain structure, which is sequentially interdependent. These sequential interdependencies are naturally still prevalent in rice supply from an operational view point. This study focuses on price transmission in intermittent trading events involving interdependency, mutual adjustments, and pricing in association with value creation which is built through interaction between the buyer and seller in the supply chain.

This research attempts to show the ways how, and the reasons why, the actors in the agri-food chains interacted and made decisions during the price transmission. First, the study contributes by describing an end-to-end supply chain analysis as a framework to get a better understanding of the social interaction among rice actors. This is in line with Engelseth (2016), who pointed out that, even in cases of market trading of commodity-like food products, relationships that integrate actors in these markets create trust and trading skills. Second, this study aims to apprehend price transmission among actors and what constitutes the interrelation between the conceptual theories and the existing conditions. Third, this study critically examines the transvection theory-based price transmission analysis (Alderson, 1965) and explores its potential connection with other theoretical frameworks.

This paper is structured as follows. The first part of the paper contains the literature review that discusses pricing and long-linked supply. The second part explains the research model based on the transvection model, value creation, and supply network. The third part presents the research model and is followed by method as the fourth part. The fifth part is the analysis and is followed by discussion as the sixth part. The last part of this paper provides the conclusion and suggestions for future research.

\section{LITERATURE REVIEW}

This section starts with the description of pricing and price transmission and is continued by outlining aresearch gap and the concept of social interac- tion predominantly associated with interdependency (Thompson, 1967) in the scope of the transvection model (Alderson, 1965).

\subsection{Pricing}

French (1997) argued that price contains market information which affects actors' perceptions (buyer/ seller) of product value and decisions during an interaction process. Vavra and Goodwin (2005) stated that price plays a leading role through sending information to align buyers and sellers in the market. Pricing is the strategic decision-making process where actors need information to determine the right unit price (Dutta, Zbaracki, \& Bergen, 2003). The three functions of pricing are: informing, providing incentive to produce, and distributing income from the ultimate buyers to retailers, wholesalers, manufacturers or owners of resources, and vice versa (Friedman, 1980; Mankiw \& Taylor, 2014).

\subsection{Price Transmission}

Bunte (2006), supported by Aramyan and Kuiper (2009), defined a situation where prices at one level of a supply chain react to changes at another level as "price transmission". In some situations, the price changes at one level are not transmitted to other levels. These levels can be interpreted as tiers in the supply chain structure. Vavra and Goodwin (2005) studied price transmission from farm prices to the retail level by measuring the speed and the extent of price changes during a transmission process. Jensen and Moller (2007) investigated price transmission patterns which can be characterized by degree, speed and type of price adjustments through the supply chain. Acosta and Valdes (2014) showed the vertical price transmission through the assessment of the nature, extent of adjustment, and speed with which disruptions are transmitted along the different actors in a milk supply chain in Panama.

\subsection{Research Gap}

Previous research on pricing in supply chains has been mainly concerned with the explanation of what technically constitutes price transmission, focusing on factors that explain price transmission as a process.In line with the price transmission phenomena, Vavra and Goodwin (2005) reviewed the mechanism of asymmetric price transmission by measuring vertical price transmission empirically along a food chain. The vertical price adjustments were 
described by the speed, direction, and magnitude relative to the initial market shock experienced by agents at different levels of the activity. Other researches on price transmission were completed and explained by Jensen and Moller (2007), as well as by Acosta and Valdes (2014). Aramyan and Kuiper (2009) stated that, to understand prices are transmitted along the agri-food supply chains, it is necessary to comprehend the chain structure and the impact of prices on each link of the chain through several factors: market power, adjustment costs, public interventions, and product perishability. According to Bunte (2006), price transmission is a market indicator among actors in the oligopolistic and oligopsonistic interdependence, which gives impact on the price adjustment lags and causes an asymmetry in the price shock reaction.

Price transmission as a social interaction has received less attention (Acosta \& Valdes, 2014; Jensen \& Moller, 2007; Vavra \& Goodwin, 2005). The primary focus of previous research on price transmission was concentrated on evaluations of the links between farm, wholesale, and retail prices. Vavra and Goodwin (2005) supported Jensen and Moller (2007) and Acosta and Valdes (2014) in using the price transmission analysis to review the mechanisms of asymmetric price transmission and in measuring the degree of price transmission to explain the speed and magnitude of price transmission. Bunte (2006) explored and analyzed the transmission of price changes from the farm level to consumer level by using the empirical data to measure pricing performance.

\subsection{Social Interaction}

Social interaction is defined as a situation in which behaviors of one actor influence the behaviors of others, and vice versa (Manski, 2000; Scheinkman, 2008; Thompson \& Hickey, 2005; Turner, 1988). Scheinkman (2008) stated that social interactions can be called non-market interactions as the interactions are not regulated by the price mechanism. Godes et al. (2005) defined social interaction as an action which is taken by an individual engaged in the selling of the product or service actively and impacts those who use the product or service. Social interaction on price transmission involves action influencing adjacent actors to communicate, seek information and transmit price information to negotiate and exchange. Social contact and communication is a condition for ongoing social interaction. Communication is the process of delivering information from a communicator to another party using symbols such as words, sounds and motion screen (Heath \& Bryant, 2012; Krendl,Ware, Reid, \& Warren, 1996).

Social interaction in information seeking is shown by actors who give price signals and conditions of commodities sold. Negotiation starting from the price signals and commodities offered does not generate up-front acceptance in the dyadic relationship. During a negotiation, a "tug of war" between a value claim and how the service is produced take places before a price agreement is reached (Bichler, Kersten, \& Strecker, 2003). The same pattern is found being used by the actors who perform transactions throughout the supply chain to transmit price information. The types of social interactions are: exchange, cooperation, and coercion (Lin, 2001; Thompson \& Hickey, 2005).

\subsection{Transvection Model}

Alderson's end-to-end marketing channels model is applied to understand the end-to-end supply chain context of price transmission (Alderson, 1965). Alderson's transvection model is mainly logistical placing focused not on transactions but on goods transformations. This model is also on how goods transformations are supported by step-wise decision-making. Transvection logic, upon understanding features of supply utility from the end-user perspective, literally traces the flow of upstream goods accounting for how goods are directed by a sequence of decision-making events or "sorts" in Alderson's term. 
Figure 1. The Transvection Model

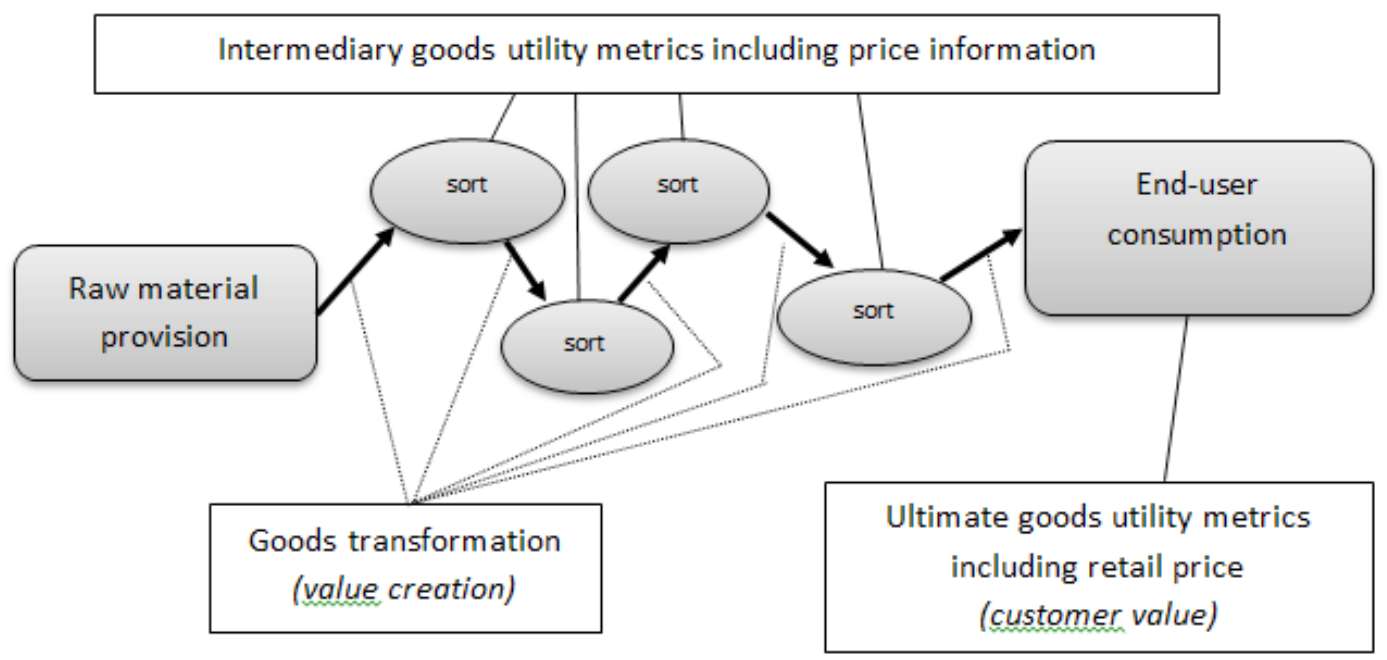

As shown in Figure 1, the goods flow represents "production", the features of the creation of the service provided (Penrose, 1959), while the objective of this flow is defined as customer value. Alderson (1965) described production as a piecemeal transformation of goods; value claiming was defined as the difference between customer-perceived benefits against costs. Adding the nature of interdependencies to this model would be to account the overall food chain as suggested by the transvection model. In physical distribution, various types of resources were combined and transformed through processes in a sequential manner. This involved planning, forecasting or buffering supply. In cases when planning failed, supplies would be rationed in these sequentially interdependent forms of supply.

Following Alderson's transvection model, actors were involved in sorts as flexible joints in the supply network structure; that is: how they were interconnected through exchange processes, how information was used to support a negotiation and interconnect people with goods transformation processes (Alderson \& Martin, 1965). Thus, transvection was more than a transaction, as it was not limited only on the successive negotiations of exchange but also included decision-making, negotiation and agreement. Case descriptions were, however, modeled based on a reverse-type inquiry and on their actual downstream flow (Engelseth, 2012), as shown in Figure 1 as a chain of value-creating events.
The transvection, in a very limited degree, accounts for the role of information in supporting goods transformation in the supply chain. As information technology develops, it is increasingly important to consider the role of information and its configuration in supporting goods supply (Engelseth, 2009). Hammervoll (2014) pointed out that logistics should increasingly consider the exchange economy as divergent from the commonly focused on production economy.

\section{THE RESEARCH MODEL}

The Context-Mechanism-Outcome (C-M-O) is applied to elaborate the research model in this study. The C-M-O points out contextual factors vital in understanding concepts that may explain price transmission and social interactions in a long-linked rice value chain (Gill \&Turbin, 2001; Pawson \& Tilley, 1997). The C-M-O is proposed to provide a view of modeling causation; i.e., how causation in the "... social world should be constructed" and that the "basic realist formula" is "context + mechanism = outcome" (Pawson \&Tilley, 1997).

Three elements that define the context of a social interaction are (1) the physical setting or place, (2) the social environment and (3) the activities surrounding the interaction (World Bank, 2010). A context is used to understand the dynamics of social interactions within communities and assessing how its various interactions relate to each other. The context in this study is identified based on social capital andused to explore the social interaction phenomena 
among rice supply chain actors. Healy and Cote (2001) defined social capital as networks together with shared norms, values, and understandings that facilitate cooperation within or among groups. This definition is supported by the World Bank (2010) and Seragedin and Grootaert (1997), who claimed that social capital refers to a society that includes institutions, networks or relationships, attitudes, values, powers, and norms that govern the interactions among actors. The actor's role consists of the behavior of someone who holds a particular status in using social networks to interact with other actors, who is bound by society's norms and who has the power to influence the interaction. Therefore, there are four contextual dimensions of social capital in this study, namely: actor's role, social network, norms, and power.

Mechanism is defined as a social explanation for human behavior that explains the interaction among actors (Prashanth, Marchal, Kegels, \& Criel, 2014). Mechanism is identified based on social interaction which refers to an action chosen by an actor. Actors use social contact and communication to influence the actions of other actors. Actors participate through social interaction (1) to obtain the information about price, condition, and needs; (2) to determine the achievement of actors' transaction goals (pricing), and (3) to find a comparison which can be used during negotiation. Thus, the mechanism of social interaction is identified through: (1) how information is used to set a price and to signal the value claiming (Engelseth, 2013) and (2) how the negotiation process occurs among actors. The actors' roles determine the positions of actors, as price setters or price takers during a social interaction. As price setters, actors seek information that is used to negotiate and set the price (pricing), contrary to price takers who tend to wait for the information.
Information seeking refers to activities connected to assessing, searching and dealing with information sources, particularly in networked environments (Choo, 1999). During information seeking, actors identify possible sources, differentiate and choose a few sources, locate or make contact with them, and interact with the sources in order to obtain the desired information (Choo, 1999; Wilson, 1999). Choo (1999) stated that the purpose of information seeking resembles a problem-solving or decisionmaking process. Actors select a source which has a greater probability of providing relevant, usable, and helpful information. The amount of time and effort influence selection and the use of sources that is required to locate, contact, and interact. Pricing as a fundamental information component influences human perception of value claiming (Friedman, 1980).

"Negotiation" is defined as a process among self-interested actorsin order to reach an agreement to satisfy preferences and constraints of the concerned actors involved (Carraro, Marchiori, \& Sgobbi, 2005; Sycara \& Dai, 2010). As a process, negotiation covers the following characteristics: (1) it involves communication among the actors involved, (2) it involves incomplete information, (3) it possibly has conflicting preferences over actions and outcomes, and (4) it is not well structured, in that there are no well-defined rules for creating legal sequences of communication actions (Sycara \& Dai, 2010). Alderson's transvection model (1965) was employed to explore how actors were involved in sorting, seeking and using price information to support a negotiation during price transmission.

Outcomes provide the key evidence to supportthe phenomena (Salter \& Kothari, 2014). The outcome of negotiation is shown through the transaction, which consists of the payment process and exchange among actors. The CMO research model is illustrated in Figure 2. 
Figure 2. C-M-O Research Model of Social Interaction on Price Transmission

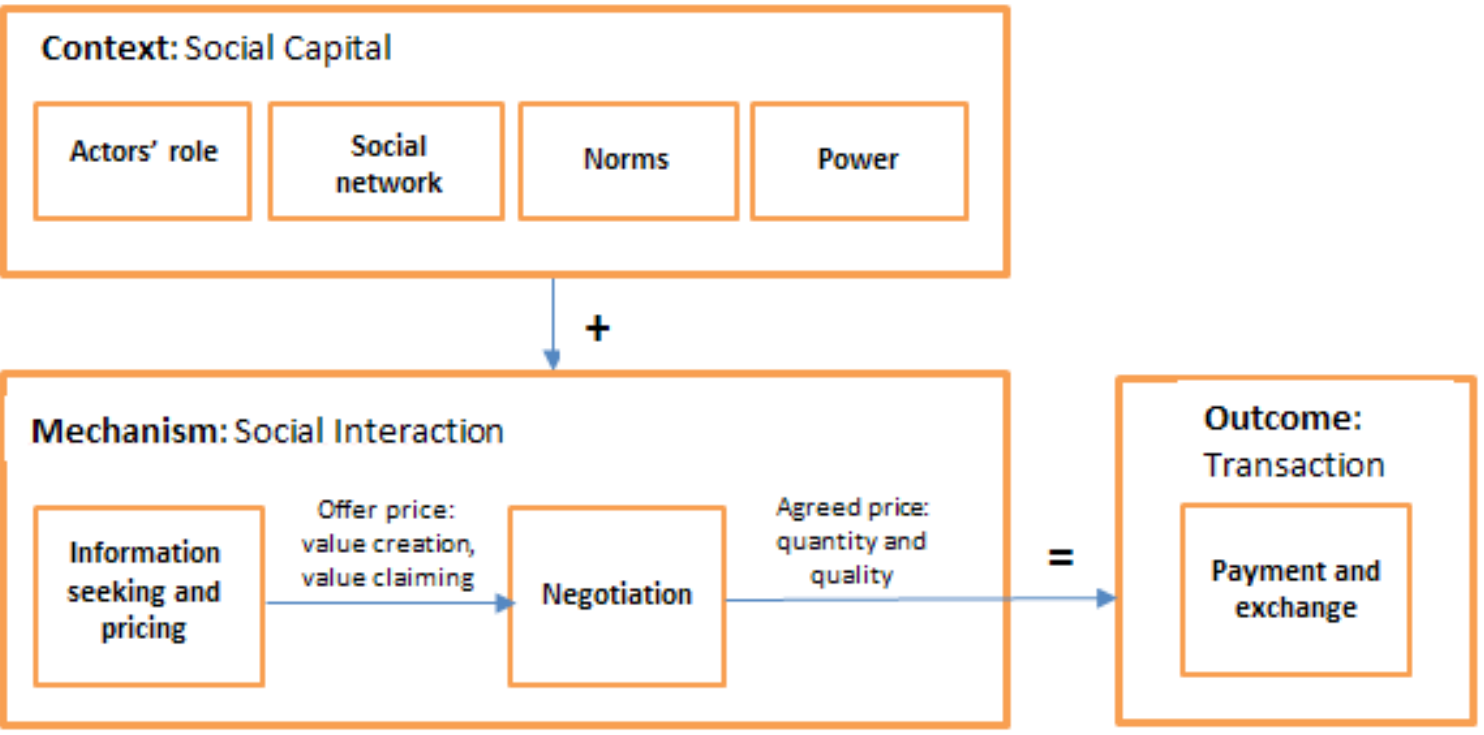

As shown in Figure 2, the actors' role consists of the expected behavior, rights, and duties of someone who holds a particular status (Thompson \& Hickey, 2005). Part of the actors' role is a local decision-making event that relies on the interaction between the product and production process, as well as between information and knowledge transformation (Engelseth, 2012). In the supply chain, a social network is the total web of an individual's relationships and group memberships that provides linkages between one individual and another (Thompson \& Hickey, 2005). Norms represent protocols or rules of behavior and commitments developed by each group to guide members in working together (Young, 2007). Norms makes human beings act predictably in certain situation and often are not written. The behavioral action norms during actors' social interaction include monitoringand information sharing. Negotiators may reach some norms when conducting negotiation. Society's norms and values bind actors' interactions and behavior (World Development Report, 2015), while power is defined as resources, ability and capacity to produce an effect or to bring influence to bear on a situation or actors (Dahl, 1957). There are two types of power in terms of resources, namely: allocative resources, which allow actors to control material objects (i.e., natural and physical materials) and authoritative resources (non-material sources of power, which result in the domination of some actors overothers) (Giddens, 1984).
Social interaction is a necessary iterative process consisting of (1) information seeking and pricing and (2) negotiations. The information seeking process involves active, via face-to-face, communication and passive information seeking through media information (Wilson, 1999). Supported by Engelseth (2009) and Alderson's transvection model (1965), transvection model is able to link pricing as value claiming to information sharing in supporting value creation.

Pricing is part of a social interaction that is associated with aspects of production and exchange connectivity (Engelseth, 2012). Following Alderson's transvection model, pricing includes the elaboration on the actors involved in value creation, how they are interconnected through exchange processes, and how information is used to support the negotiation and interconnection among actors as well as between actors and goods transforming processes. Festinger (1954) argued that information is the prime motive for negotiation. Forget, Monteiro, D'Amours, and Frayre (2008) stated that negotiation is used as a coordination mechanism to find an acceptable agreement between partners. Phillips, Simsek, and van Ryzin (2014) stated that prices are negotiated among participating actors and are used to determine the final price. A transaction would not occur if the seller's priceis greater than what the buyer is willingness to pay and vice versa (Phillips, Simsek, \& van Ryzin, 2014). This is consistent to Friedman (1980), 
who said that pricing acts as a fundamental information component that influences human perception of customer value or economics exchange. The social interaction outcome of an agreed negotiation is called a transaction, which covers two activities, namely: payment and exchange.

\section{METHOD}

This research employed a case study to analyze social interactions during price transmission in a rice supply network. Two main components were studied, namely the long-linked supply network and pricing, with a focus on price transmission and the rice actors' behavior in the decision-making process. The method of this research is a case study, which isconsidered suitable by Yin (2013) because it tries to answer the research questions "how" and "why". This study attempts to understand the social interaction phenomena among actors in the supply chain, and how and why the actors in the agri-food chain interacted and made decisions during the price transmission. Following Pagell and Wu (2009) and Ketokivi and Choi (2014), a case study fits to the phenomenon of social interaction in describing price transmission.

This study is focused on price transmission, in which social interactions in the rice supply network is regarded as a unit to be analyzed. Based on a preliminary study, the selection criterion for the region was built on having the complete representatives of different rice actors in the region and the possibility to trace the price transmission process among rice actors, and the region was part of major contributor to the national rice production. Thus, the Karawang district, in West Java, Indonesia was chosen. The next step is to apply the research model in Figure 2 to the empirical evidence of the rice supply in Karawang District.

All informants in the area were contacted in the field and asked about their willingness to take part $t$ in the study. During the research, observations and interviews were conducted to obtain a better understanding about social interactions in the rice supply network. Semi-structured interviews were used. First, it was important to get complete information about the actors involved in Karawang District rice value chain with the different actors' roles, and a semi-structured protocol gives the researcher the flexibility to focus on what is unique about each actor's role in the rice value chain. Second, there was some theoretical supporting for items included in the protocol such as C-M-O. So, it was important to understand how social interaction and price transmission issues were addressed using $\mathrm{C}-\mathrm{M}-\mathrm{O}$ as a contextual approach.

Multiple investigators were employed as part of testing the research validity, because peer review enhances confidence in the findings and allows the case to be viewed from the different perspectives of multiple observers (Yin, 2013). In order to triangulate, each investigator in this study used the same method, namely in-depth interview, observationand probing. The actors' gestures in transaction activities were observed and noted, as part ofthe research's internal validity process. The observation during this research covered watching what the actors did, listening to what they said and sometimes asking for clarification. During observations, some notes and pictures were taken regarding the issues observed. For important issues, probing and active listening were used to obtain more information. The purpose for this was to find the non-verbal essence of trading events (Yin, 2013). Probing included conducting indepth interviews with respondents.

Nineteen farmers, nine millers, three traders and one wholesaler were interviewed and observed. In total 60 hours of interviews took place. The interviews were conducted on site. Each quote and comment in the Sudanese language was translated into English. The use of a Sudanese translator helped researchers to understand unclear taped conversations taken of several of the interviewees.

The qualitative research validity was taken by exploring the depth, richness and honesty of the data, triangulation, and the objectivity of the researcher (Cohen,Manion, \& Morrison, 2005). The internal validity of the study was achieved through all the questions asked to the respondents, based on the research aims and research phenomena. The generalization, as part of the external validity, was made by observing similar or the same responses on topics from respondents on the interview transcripts. To ensure reliability, several steps were taken during the study: all questions were asked in a natural voice, using clear wording and the interviews were recorded. Any unclear questions queried by respondents were repeated and no interventions were made by the researcher through gestures or unnecessary comments during the interview sessions so that respondents were free to describe their thoughts and beliefs. 


\section{CASE STUDY: SUB-DISTRICT OF TIRTAMU- LYA, KARAWANG DISTRICT}

The Karawang District is located in the nothern part of the West Java Province and covers an area of 1,753.27 $\mathrm{km} 2$ or $3.73 \%$. Karawang has fertile soil, suitable for agriculture, which supported by three irrigation areas located in Karawang: North, Central and West Tarum. These irrigations are used for rice fields, brackish water ponds and electricity. The area of rice paddy fields in the Karawang Districtc overs around 98,079 hectares, and the District employs technical, semi-technical and non-technical irrigation systems. The rice supply chain in the District is carried out by various operators. The majority of traders and millers in the District operate through network relationships to ensure not only the smooth flow of rice but also the working capital. The relationships and social networks are largely determined by contacts and by the ability to command the buying and selling price. In this study, rice actors, agricultural shop owner, farmers, village intermediaries, wholesalers, and agricultural extension workers.

\section{Context: Actors' Role, Social Networks, Power, and Norm}

Actors' Role

The rice actors in the KarawangDistrict are classified into five operating groups, namely: agriculture shop owner, farmers, village intermediaries, wholesalers, and agricultural extension workers. The input supplier is categorized into seed and fertilizer suppliers, agricultural tools suppliers, capital owners and land owners. The five operating groups act as follows. The agriculture shop owner provides inputs to the suppliers, as shown in the following statement:

"We provide the suppliers such inputs as seed, fertilizer, pesticide and tools to be supplied to the rice farmers." (Saprodi Shop A, Tirtamulya)

The farmers' role in the rice supply chain starts from the production process, from planting the rice seed until harvesting. Afarmer's rice field is between 1 and 2 hectares. Rice farming activities include planting, growing and harvesting. This is made evident by the following statement:

"Farmer production is planting Ciherang seed, growing and harvesting." (Farmer C, Pasirmalang)

The farmers' ability in determining the paddy planting period, rice price increases, and good seed quality is supported by the following statements:
"The price of rice crops increasefrom December for the next three months." (Farmer A, Tirtamulya)

"The quality of Ciherang seed produces good rice crops." (Farmer C, Pasirmalang).

The brokers or traders work is based on profit commission from such activities as milling, drying and transporting. Brokers, as capital providers for farmers, can be found during planting and harvesting. The role of rice mill owners is to process rice cropsinto milled rice. The transporters collect unhulled paddy or milled rice and transport it to the intermediaries or wholesalers in central markets. The main activities of traders in sub-districts or villages are to buy rice crops in a certain quantity from farmers and sell the milled rice in various types and quantities to wholesalers. The traders' role is supported by the following statement:

"We buy rice crops from farmers and transformthem into milled rice." (Trader B, Tirtamulya).

At the central rice market, wholesalers stated that they buy rice from West Java and Central Java as they have capital to buy various types of rice and rice in large amounts. The transaction at the central market is conducted by cash payment and pricing is based on rice quality (grading and moisture). The wholesalers' role is stated in the following statement:

"We buy rice from many traders coming from West Java and theCentral Java area." (Wholesaler A, Central Market)

The government extension workers in the District help farmers by giving out free samples of good seed, advising them on how to apply planting patterns to maintain soil fertility and conducting an irrigation rotation system. The role of agricultural extension workers is as stated as follows:

"We organize an irrigation system to ensure two harvests time per year. We advise farmers how to apply planting patterns for paddy and palawija. These patterns are implemented to avoid pest attacks." (BP3K, Tirtamulya)

\section{Social Networks}

The interviews show that farmer A is interconnected with the agriculture shop in terms of paddy seed, fertilizer and pesticide during planting and harvesting, as is described in the following statement: 
"I buy seed, fertilizer and pesticide from an agriculture shop." (Farmer A, Tirtamulya)

Famer B in Sukajaya stated that:

"The agriculture shop owner allows credit payment for seed, fertilizer and pesticide."

Farmer and regular trader networks were apparent through the rice crops transactions. Farmer A stated that, during harvesting, he went to the village traders to offer his rice crops:

"I go to traders' houses to offer our rice crops." (Farmer A, Tirtamulya)

Farmer B stated that during the harvesting season, village traders visit his rice field:

"During the harvesting period, the regular village trader visits our rice field." (Farmer B, Sukajaya)

Both farmers A and B confirmed that regular village traders acted as part of their networks.

A similar network was found at trader level. Trader $B$ was linked with particular farmers and either they came to his house or he visited them:

"...I have regular farmers who usually visit my house. But sometimes I visit them in their rice field." (TraderB, Tirtamulya)

Trader A networks with his regularwholesaler through the milled rice heoffers.

"I deliver milled rice to my regular wholesaler at Central Market." (Trader A, Tirtamulya)

Power

Farmers do not have enough storage to keep theirrice crops and have little power to allocate resources owing to financial risks, such as: low quality and quantity of rice crops because of a pest attacks dry seasons, or higher production costs. This is confirmed in the following statement:

"Sometimes we are facing financial loss due to a pest attack, a dry season, a higher input production cost or low buying price. But, still farmers continue their activities as they are already in the production stage." (Farmer A, Tirtamulya)

The traders commonly have one or two milling machines, a dryer, and a storage facility with a capacity for around 5-8 tons ofmilled rice, and they collect rice crops from farmers in their respective areas. Traders have the power to set the price because they have the capacity storage and capital. The following statement confirms:

"Traders in this area have one to two milling machines, one storage with the capacity of around 6-7 tons to stock milled rice and rice crops, and they generally have one dryer. (Trader B, Tirtamulya)

Trader C stated that both the moisture of rice crops and the color of seed are used to determine the quality and price offered to the farmers:

"In checking the quality of rice crops, we check the moisture and seed color by taking out around 20 seeds from the rice crops. A clear color indicates that the quality of the rice crops is good." (Trader C, Tirtamulya).

Wholesalers have both more capital and storage capacity for buying the traders' milled rice. Wholesalers determined the amount and the quality of rice being offered, as is shown in the following statement:

"We buy rice from traders who frequently come to our place. The buying decision is determined by the rice quality and quantity, price being offered, and capacity storage." (Wholesaler A, Central Market)

Wholesalers offer a price to traders based on the quality of the milled rice. Wholesalers conduct random checks on the moisture and color; good quality is indicated by such physical characteristics as color (clear but not white) and shape (round or oval). This is confirmed by the following comment:

"We check the quality of traders'milled rice based on several physical characteristics, such as the moisture, the color and the shape of the milled rice. If all the characteristics are acceptable, then we offer the price." (Wholesaler A, Central Market)

\section{Norms}

Farmers commit to sell crops to regular village traders and conduct buying and selling activities with others, if necessary, using brokers or informants, as described below: 
"We prefer to sell our rice crops to our regular traders. We use informants or brokers for selling our rice crops to other village traders when harvests occur simultaneously in several areas at the trader level." (Farmer B, Sukajaya)

A similar situation also applies to traders, as is stated below:

"The rice crop is supplied by regular farmers in respective areas. Buying from other areas has to be done by villager brokers or rice informants." (Trader B, Tirtamulya)

The interaction between farmers and traders is based on their belief that they will support each other. The interviews showed that, if farmers are in trouble, assistance comes from either a family member or a trader who has built a relationship with them. The relationship among actors is not only based on a commercial basis, but on family, religious or ethnical links.

"Assistance is given by either a family member or even a trader if we suffer a financial loss or financial trouble." (Farmer A, Tirtamulya)

"Family support is important when we encounter difficulties as a farmer, and this will enable us to continue." (Farmer D, Pasir Malang)

Traders conduct only random checks onthe quality of rice crops as farmers are considered to provide honest and accurate information about their crops' quality:

"We do not check all the rice crops as we believe that farmers do not mix their rice crops with other lower quality crops." (Trader B, Tirtamulya)

Traders have the capital for buying and paying in cash for rice crops in the different qualities and quantities being offered by farmers, as is stated in the following statement:

"Rice crops are bought based on the quality and quantity and our storage capacity as well. The transactions are based on an agreed price and paid in cash." (Trader B, Tirtamulya)

\section{Mechanism: Information Seeking and Pricing, and Negotiation}

Social interaction is used by actors to obtain recent information about price and supply conditions. Farmers receive price information from their social network by visiting a trader or other farmers. Farmers only tend to seek price information to compare it with their offering price.

"The price information is brought by traders. Sometimes we check the price by asking other farmers about the price. There is no other information source." (Farmer B, Sukajaya)

Traders seek information by sending short text messages to their informants or visiting wholesalers.

"We use the telephone to contact wholesalers or send short text messagesto our informants to get up-to-date price information at the Central Market." (Trader B, Tirtamulya)

As price setters for traders, wholesalers use price information at the central market to inform traders of the buying price. Wholesalers transmit price information by sending short text messages to traders or transporters.

"The buying price information at the Central Market is transmitted to traders or sometimes to transporters who deliver rice to our stores. The amount of buying rice supply stocks is based on our storage capacity and quality of rice crops." (Wholesaler A, Karawang Central Market)

The pricing process between farmers and traders or traders and wholesalers is based on the rice quality and storage capacity. All actors are involved in seeking and using information to support pricing. Traders use value creation as information to determine value claiming to farmers. Traders determine their offer price based on information received from trader network or wholesalers. Traders' knowledge and experience are used to determine the rice crops' quality, the rice supply in the market and the profit (i.e profit is defined as how well actors control the costs over revenue). This is supported by the following statement:

"Current price information from wholesalers or traders is used to determine pricing for farmers. The offer price also considers several factors such as quality, quantity, profit and rice supply stocks." (Trader B, Tirtamulya)

Similar to traders, wholesalers use market price information, rice quality and capacity storage for pricing to traders as stated below:

"Pricing to traders is based on current market information, quality of traders' milled rice, rice stocks and target profit" (Wholesaler A, Karawang Central Market) 
Based on the interviews, farmers expected prices to increase in every year from December until March, due to the rain season, a different harvesting period, the quality and quantity of rice production and a shortage of rice stock at the market.

“... based on my experience, the price of rice crops increase from December for the next three months." (Farmer A, Tirtamulya)

Based on the interviews about negotiation, Farmer A stated that the farmers' actual selling price of the rice crop covers only the farmers' production and harvest costs.

"Traders check the unhulled paddy quality before giving the price. The production cost includes seed, fertilizer, pesticide, maintenance, and rice crops." (Farmer A, Tirtamulya)

A transformation process or value creation is used to determine the quality and pricing from traders to farmers, as stated in the following statement:

"I check the quality and quantity of the farmers'unhulled paddy before offering the price. Negotiation is rarely used because most farmers have already had price information. The price offered to the farmers covers three activities: milling, storing and transporting." (Trader B, Tirtamulya)

The wholesaler pricing process is based on the rice quality offered, as stated by trader B.

"The value creation from the farmers' rice crops to the traders' milled rice has an impact on the quality and the offer price to traders. The information received by traders about the quality of milled rice supports the pricing from traders to wholesalers." (Trader B, Tirtamulya)

Farmers have little power in negotiations due to the limited resources they own. Thus, the price traders offer to the farmers tends to be approved by the traders. Traders are price setters for the farmers. This situation is evident in the following statement:

"We conduct a price agreement with the farmers. This means when the farmers'offer price is too high, we bargain with the farmers. If the farmers agree with the bargain, then we buy the rice; but sometimes the price is directly agreed without negotiation." (Trader C, Tirtamulya)
As price setters, traders use their relationship with the farmers, their capital and storage capacity and the quality of rice crops to obtain their excess amount.

"The selling price of the rice crop is based on the quality of the rice crop and my capacity (money and storage). And sometimes I also consider my relationship with regular farmers in determining my buying price.". (Trader B, Tirtamulya).

Traders in this study also stated that wholesalers have more capital so they can determine both the quantity of rice to buy and the offer price at the market.

"The selling-buying prices are based on the moisture quality and quantity of the milled rice offered by regular traders and my storage capacity." (Wholesaler A, Karawang Central Market)

Based on observation, both wholesalers and traders exercise information and power (experience, capital, regular relationships, and storage capacity) and networks in relation to selling actors. Negotiation is based on the quality and quantity of both the rice crops and the milled rice, and this occurs only if the traders' buying price is lower than sellers' expectations.

\section{Outcome}

The interviews show that sales are not forced on to actors. There is no price-based competition among farmers, traders, and wholesalers. Statements made by all respondents say that transactions and negotiation are based on relationships. The payment scheme adopted is cash and carry.

"The payment scheme is cash and carry." (Farmer A, Tirtamulya)

Sellers (farmers, traders, and wholesalers) understand that the buyers' willingness to pay is based on a pricing process which is dependent on the quality and quantity of both the rice crop and rice milled.

"Payment is based on the agreed price, which is based on the quality and quantity of the rice crops." (Farmer A, Tirtamulya)

Like farmers, the wholesalers also state:

"The agreement between wholesalers and traders is according to the offer price, which is based on the quality and quantity of the milled rice." (Wholesaler A, Central Market) 


\section{Price Transmission}

From the interviewes, $\Delta \mathrm{Pf}+$ indicates the increasing price of the production input at the farmer lev$\mathrm{el}$, which is countered by $\Delta \mathrm{Pt}+$, which indicates the increasing price at trader level. $\Delta \mathrm{Pt}+$ indicates the increased price of production input at trader level, which is countered by $\Delta \mathrm{Pw}+$, which indicates the increasing price at the wholesaler level. Farmer interviewees argued that, when the rice price at the market increases, farmers still did not benefit from the situation. On the contrary, when the market price decreases, the adjustment of the wholesalers' buying price of rice is fast and directly affects the adjacent actors. Figure 4 describes price transmission among actors in the Karawang District.

Figure 4. Price Transmission along the Rice Supply Chain

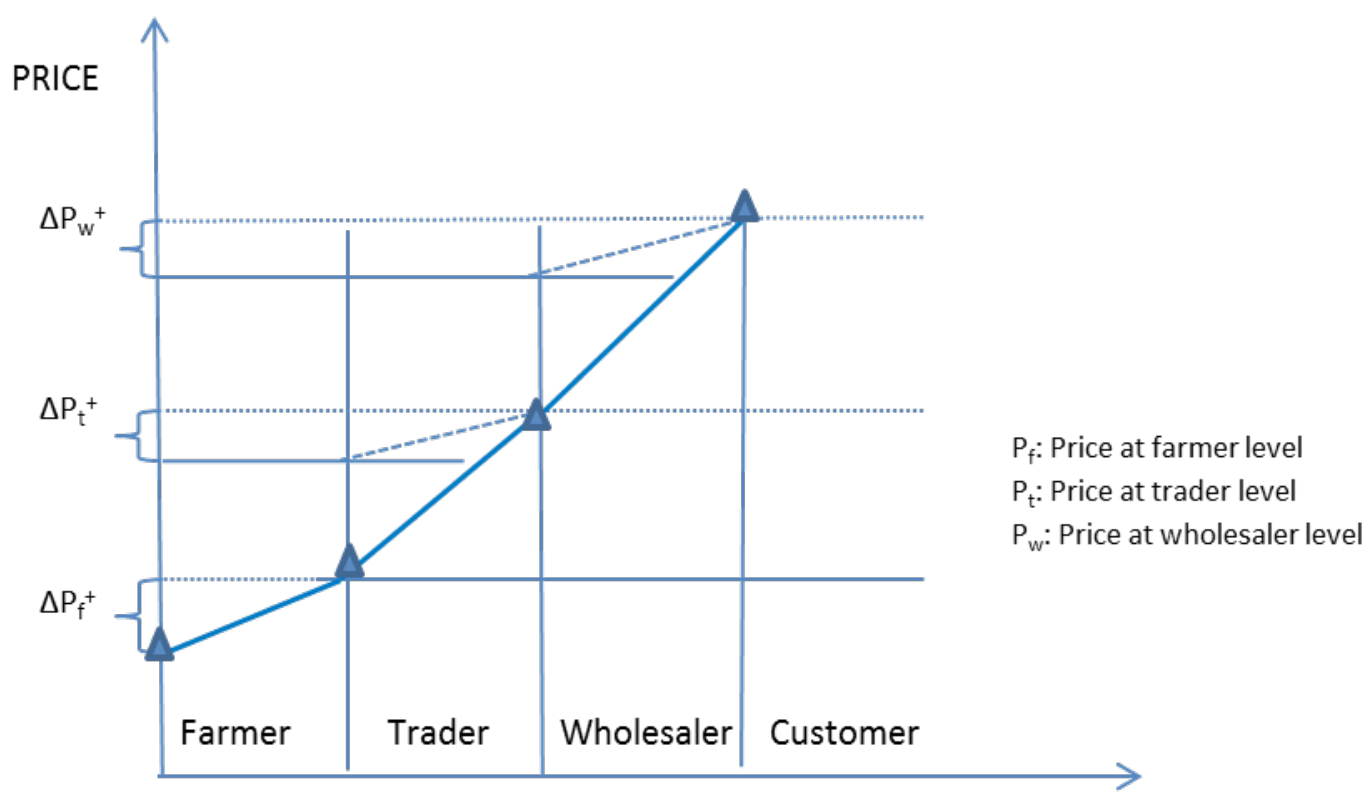

When the market price increases, wholesalers tend to keep the information hidden due to stocks' availability. The social interaction between wholesalers and traders during increased prices is dominated by power (market stock availability and information). Moreover, based on his experience, wholesaler A has the ability to identify the period of increased prices and to set the price to market, as stated in the following statement:

"Based on my experience, prices increase from December to March, but it depends on the rain fall and my storage. Mostly, I buy once the price drops and sell when the price starts to increase. The information about the increased price is accessed by traders through their transporters or short text messagessent by other traders. I do not inform other traders of the increased prices as I have enough stocks at the storage. The increased price has an impact on my expected target profit." (Wholesaler A, Central Market)
On the contrary, when the market price decreases, wholesalers inform traders, as stated in the following statement:

"But when the market price decreases, we inform traders and mostly traders will respond by adjusting their offer price." (Wholesaler $A$, Central Market)

Traders seek information from wholesalers regarding up-to-date price information:

"Usually, wholesalers respond to the increased market price fast and keep the information of the increased price secret. But when the market price decreases, wholesalers respond to this situation immediately by sending short text messages to me or to my transporters." (Trader B, Tirtamulya)

Traders have no ability to respond to the increased price, but have power to respond to the decreased 
price due to their having capital, rice stocks and quality rice stocks by adjusting their offer price to farmers. Traders inform farmers regarding falling prices by immediately sending short text messagesor by visiting regular farmers' rice fields. This is stated in the following statement:

"When the market prices fall, wholesalers inform traders through short text messages and I deliver this information to farmers as well. This can be done through sending short text messages or visiting farmers' rice fields. The price adjustment made by traders are based on famers'offer price." (Trader C, Tirtamulya)

Farmer A stated that when the offer price of rice crops increases, due to the increased cost of the production input, he informs traders by visiting them in their houses or by sending them short text messages. The increase of the farmers' offer price is not immediately responded to by traders. This situation is reflected in the following statement:

"When both the price of production input and the offer price increases, I inform traders directly through short text messages or during trader visits." (Farmer A, Tirtamulya)

When the market price increases, wholesalers determine their target profit by keeping the price information secret to traders, unless traders ask the wholesalers about it. Moreover, wholesalers are able to store more milled rice when the buying price of milled rice decreases. On the contrary, when the market price decreases, wholesalers inform the traders of the decreased price and adjust the buying price of the milled rice to traders immediately, as is stated in the following statement:

"But when the market price decreases, I inform traders of the decreased price and adjust the offer price to traders. Negotiation takes place if the wholesaler feels that the traders'offer price will reduce the wholesalers' target profit." (Wholesaler A, Central Market)

Similarly, traders adjust the price according to the information about the decreased price made by wholesalers. The wholesaler receives higher profit than trader as its cost only covers warehouse, transportation to customers and labor, while the trader bears several activities such as milling, drying, storing, transportation, and overhead cost. The wholesaler's capacity storage and number of customers contribute to wholesale profit realization as well.
Based on interview, wholesaler agreed that amount of capital, storage capacity and number of customer of wholesaler were more than trader. It can be stated that wholesaler receives higher profit than trader as stated as follow:

"Negotiation takes place if wholesalers feel that the traders' offer price will reduce wholesalers receiving a certain amount of profit. The storage capacity, quality and capital, up-to-date price information, rice supply in the market and expected target profit determine the adjustment of the offer price to traders. I am able to set the market price as I manage market storage. But there is no competition among wholesalers at the Central Market." (Wholesaler A, Central Market)

"I adjust the offer price against the wholesalers' offer price, and negotiation takes place if traders feel that the traders' received profit is lower than expected. The traders' target profit is adjusted by considering such factors as transportation cost, milling cost, rice supply, quality, quantity and up-to-date market information. All of these factors have an impact on traders' margin." (Trader B, Tirtamulya)

However, the profit gained by traders is better than that received by farmers. Traders determine the offer price, based on the quality of rice, capacity storage of rice, capital, and rices tocks at the market. Farmers determine their offer price based on the quantity and quality of the rice crops. The risk of pest attacks and dry season influence the farmers' production costs and the farmers' target offer price as well. Farmers are the risk takers compared to traders, as farmers have a limited power to determine their target margin because they have less authoritative (less capital and no storage) and allocative power to set the price, as is confirmed in the following statement:

"Traders bring unhulled paddy, based on the rice crops' quality, from regular farmers. Quality is important to traders as good milled rice is determined by the good quality rice crops. While getting a good quality rice crops sometimes requires more expenses, such as more fertilizer cost, good seed and good monitoring from the planting period until the harvesting period. Therefore, the farmers' profit is not as big the that of traders, as farmers have less capital to set the price than the trader does." (Farmer D, Tirtamulya) 
Another reason to lowered margin for farmers is due to rice as a perishable good, both wholesalers and retailers are reluctant to increase their buying price as they bear the risk of being left with a spoiled product. This often occurs when rice available abundantly after harvesting period, farmers do not have other alternatives to accept lowered selling price.

\section{DISCUSSION}

The farmers, owing to having limited capital and no storage for their rice crops, have no power to set the selling price. The farmers, as price takers,compare the information they receive with their offering price. The traders or wholesalers use the information they receive to determine their target profit. It can be seen that both the wholesalers and traders receive greater target profit from the rice prices than the farmers. This fact is in line with the claim made by Vavra and Goodwin (2005). Their claim said that traders use their power to employ pricing strategies which result in complete and rapid cost increases but slower and less complete transmission of cost savings.

This study found that pricing is embedded in a supply network; hence profit received by actors in the supply network increases along the rice supply network from farmer, through trader, to wholesaler. The study also revealed that several rice actors could receive unfavorable prices, owing to a lower quality of rice crop or pest attacks, which thus affected their target profit. Aramyan and Kuiper (2009) considered the dry season, cost adjustment, and power to be the factors that explain price transmissions. The costs that farmers have to obtain their rice crops include: input production, planting, and maintenance; while the costs that traders have include: milling, drying, storage, and transporting the milled rice. For those actors, the profit they receive depends on both the information about rice prices in the market and the rice stocks of the wholesalers. This condition is supported by French (1997), who stated that market information is embedded on value creation of products and this influences actors' behaviors and decisions during interaction processes.

Moreover, the study conducted by Friedman discovered that the social interaction between farmers and the village traders had been formed as the traders received rice crops from regular farmers. It showed that pricing is built through regular relationships between the actors, which is a sort of mechanism to make a pricing decision without a centralized direc- tion, and sometimes without requiring the actors to speak to one another or to like one another (Friedman, 1980). The pricing process among the actors in the Karawang District enables them to cooperate and maintain their relationships in terms of transactions. This research also found that the farmers, traders, transporters and wholesalers valued their social relationships. This situation is supported by Fafchamps and Minten (1999), who showed that a relationship is fairly valuable as a majority of traders reported that it was very difficult for them to find a new supplier if they lost one. Social interaction enables actors in a rice supply chain to deal with supply allocation in order to maintain the regularity of rice supply among actors.

This study shows that the price relationship between the farmers and traders tends to be asymmetric, as the farmers argued that the net profit hey receive is lower than the traders. It indicates that the traders use their power, norms, networks and roles to claim value from the farmers. But, the traders said the wholesalers use their power and roles to set the price, i.e., through their capital, rice stocks and information. Thus, the wholesalers have the ability to determine the retailers' and farmers' rice pricedue to their allocative (capital and stocks) and authoritative power (information). This situation is supported by Vavra and Goodwin (2009) and Jensen and Moller (2007), all of whom mentioned that the slow responses among actors are related to storing, transporting, and processing agri-food products, as well as to their adjustment to the condition at retail and the nature of price reporting. Therefore, in agrifood chains, a response to retail prices, to changes in wholesales or farm level prices is not immediate, but distributed over time (Acosta \& Valdes, 2014).

In this study, the willingness of the traders to accept the rice crops being offered by the farmers shows the level of relationship between traders and farmers. This interaction is based on the norms of regular relationship of both actors in conducting selling and buying activities. This fact is supported by Syahyuti (2008) and Fafchamps and Minten (1999), who stated that an economic activity relies on one's willingness to take a risk that facilitates transaction and pushes a collective action at the end. Moreover, Syahyuti (2008) said that social norm is an unspoken and unwritten bond among actors, and this situation is also applicable in Karawang, as the farmers and traders said that they used informants or brokers for the transactions outside their village area. This situ- 
ation was identified during the interviews and observations of the actors' networks in the Karawang District. It can be stated that the social norms form acceptable behaviors that are highly valued. With such social norms, the cooperation and relationship among the actors work well without the need for legal or formal regulation to regulate their interactions in the Karawang District.

The case illustrates that rice being a physical product, the value creation was analyzed in sequential order in the rice supply chain. Value creation was used as the information to determine value claiming. The study reveals that the traders act as intermediaries between the wholesalers and the farmers through established social interactions and transactions. By applying the transvection model, sorting the intermediary activity is associated with the value creation management that is done through coordinating the rice crops of the farmers' value perceptions and their intermediary value perceptions in terms of a transformation process. Value claiming in exchange contains the actors' perception about the quality and quantity of the rice crops or milled rice, rice stocks, target profit and information exchanges to determine an offer price.

Theoretically, actors should be dominantly and sequentially interdependent (Alderson, 1965; Thompson, 1967), but this case study indicates that the actors' activities are guided by social interactions that are varied, depending on their institutionalized norms of conduct. The transvection model is considered to contribute in giving an understanding of value rice creation and value claiming among the rice actors in the Karawang District. The uncertainty of both the rice stock and the price are controlled in the Karawang case by the social network, power, and norms in the supply network. In other words, it is controlled not through technical integration but through developed social interactions; network and norms are used to deal with obtaining the assurance of supply allocation, and power is used to determine offer prices (Fafchamps \& Minten, 1998, 1999; Syahyuti, 2008).

Therefore, how actors think, decide, and act during an interaction process and a price transmission process helps to describe and explore the pricing mechanism among actors. Patterns of social interactions shown through a price transmission among actors can be developed and studied analytically. The achievements of farmers' and traders' common goals can be identified through transaction ac- tivities. Friedman's study found that during social interactions, actors not only transmit information but also distribute income through value claiming (Friedman, 1980). In this case study, the actors tried to find other actors within their social networks to get and simplify the information process by focusing on pricing and negotiation. Thus, social interaction among actors during price transmission included: discussing the relationship between prices at market, conducting information seeking, setting pricing, and conducting negotiation processes. This study also shows that social interactions are influenced by roles, networks, norms and power. Power is concerned with resources or the ability to bring influence to bear on a situation or actors, while norms are concerned with the commitment developed among the actors in their selling and buying activities. Thus, the patterns of their social interactions are associative interaction ones, which encourage the achievement of accommodation and adjustment. Therefore, this case study provides an explanation of actors' social interactions on a price transmission along a rice supply chain.

\section{CONCLUSIONS}

This research reveals that the price transmission among actors is guided by a social interaction which is varied among actors and is dependent on the established social norms, power, and network as well. This case study shows that information at the central market was obtained through personal contacts with other wholesalers, traders, farmers, or through messengers, while the role of public sources, such as the newspaper, radio or public services is marginal. The negotiations show that value claiming has been influenced by regular relationships, which are shaped by social interaction, power and norms of social networks among the actors. In the absence of formal institutions, social capital seems to play its role, i.e., in mitigating the rice-related risks such as high price fluctuations, pest attacks and weather anomalies.

It can be stated that there are three reasons why the actors participate in social interactions. They are (1) to obtain information about the up-to-date condition, quantity needs, and offer price of the rice crops in a more confident transaction, (2) to become involved from the beginning to create a sense of belonging and sense of responsibility; and (3) to achieve their target profit in their own transactions. The study shows that daily social interactions among the actors are followed by social actions. 
This case study has contributed in the creation of methods for exploring a price transmission process among actors' social interactions by integrating the transvection model into a long-linked rice supply chain. The discussion describes and analyze the case of social interaction during price transmission. The most important finding of this case study is that the asymmetric price roles cause adjustments to behaviors during the interactions. This situation occurs when the market institution is weak, which makes traders and wholesalers become more efficient in developing their credible suppliers and networks to allow more simple ways to trade: granting and receiving transaction offers, forwarding orders and simplifying quality checking. Therefore, the use of the transvection model helps to explore the social phenomena during the actors' interactions through the value creation (product transformation) and pricing process (value claiming). This study contributes several outcomes, namely (1) generating a new approach to explain and identify the factors affecting the price transmission and (2) describing and explaining the social interactions among the actors in the price transmission phenomena.

Logistics researchers argue that managing a supply chain is not the same as operating a machine. The supply chain is a social structure where interactions between humans create solutions, which represents both the patterns of exchange and production. The economy of production is vital in rice supply since this is a form of physical distribution where features of rice transformation are directly associated with value creation. The use of the C-M-O as a contextual approach provides a better understanding on social capital as a context, and social interaction as the mechanism to explain price transmission among actors. This research provides evidence that integrating the transvection theory into social interaction phenomena during a price transmission is important to create knowledge about value of norms and power by which actors are facilitated to get a shared understanding during price transmission. The benefits of social capital for the rice actors are shown in a reduction in the high transaction costs as traders and farmers are able to deal with each other in a more trustworthy manner by granting and receiving price offers, in price information exchanging, and in economizing quality inspections.

The evidence indicates that the relationship between the farmers and the transporters helps the traders to economize their transaction costs. As for the re- lationship between the traders and the farmers, it helps them to receive a better profit. However, in agricultural commodity trade, the presence of social networks enables the traders to reduce their transaction costs in a situation of imperfect information while gaining higher profit. To the academia, this research could assist more scrutinized research and aid in analyzing a price transmission in an agri-food supply chain. In order to empower rice farmers, researchers must consider the existence of social interactions between farmers and village traders (traders, millers, and transporters). In this case study, the social value is found when analyzing the agricultural commodity trade.

The use of a single case study addresses the phenomena of social interactions in price transmission along a specific rice value chain. The description might vary when applied to other value chains due to different social settings. Further work should be focused on confirmatory studies where multiple case studies are conducted to confirm the price transmission phenomena in a long-linked rice supply chain. While the result of this study demonstrates the significant effect of social interaction on price transmission in the rice commodity of an economy, it would be useful to extend the study to other commodities or sectors.

\section{REFERENCES}

Acosta, A., \& Valdes, A. (2014). Vertical price transmission of milk prices: Are small dairy producers efficiently integrated into markets? Agribusiness Journal, 30(1), 56-63.

Alderson, W. (1965). Dynamic marketing behavior: A functionalist theory of marketing. Homewood, IL: Richard D. Irwin.

Alderson, W., \& Martin, M.W. (1965). Toward a formal theory of transactions and transvections. Journal of Marketing Research, 2(2), 117-127.

Aramyan, L.H., \& Kuiper, M. (2009). Analyzing price transmission in agri-food supply chains: An overview. Measuring Business Excellence, 13(3), 3-12.

Bichler, M., Kersten, G., \& Strecker, S. (2003). Toward a structured design of electronic negotiations. Group Decision and Negotiation, 12(4), 311-335.

Bunte, F. (2006). Pricing and performance in agri-food supply chains. In C.J.M. Ondersteijn, J.H. M. Wijnands, R.B.M. Huirne, \& O. van Kooten (Eds.), Quantifying the agri-food supply chain (pp. 37-45). Rotterdam: The Netherlands: Springer.

Carraro, C., Marchiori, C., \& Sgobbi, A. (2005). Advances in negotiation theory: Bargaining, coalitions and fairness [Policy Working Paper No 3642]. Washington, DC: The World Bank.

Choo, C.W. (1999). Closing the cognitive gaps: How people process information. London: UK: Financial Times of London. 
Cohen, L., Manion, L., \& Morrison, K. (2005). Research methods in education (5th ed.). London, UK: Routledge Falmer.

Dahl, R.A. (1957).The concept of power. Behavioral Science, 2(3), 201-215.

Dutta, S., Zbaracki, M.J., \& Bergen, M. (2003). Pricing process as a capability: A resource-based perspective. Strategic Management Journal, 24(7), 615-630.

Engelseth, P. (2009). Food product traceability and supply network integration. Journal of Business and Industrial Marketing. 24(5/6), 421-430.

Engelseth, P. (2012). Modelling transformations in a complete fresh food value network. In H. Jodlbauer, J. Olhager, \& R.J. Schonberger (Eds.), Modelling Value (pp. 373-391). Selected papers of the 1st International Conference on Value Chain Management. Berlin, Germany: Physica-Verlag.

Engelseth, P. (2013). Multiplex uses of food product standards. International Food and Agribusiness Management Review, $16(2), 75-94$.

Engelseth, P. (2016). Aligning end-to-end seafood supply through a series of markets. International Journal of Production Economics, 173, 99-110.

Engelseth, P., \& Felzensztein, C. (2012). Intertwining relationship marketing with supply chain management through Alderson's transvection. Journal of Business and Industrial Marketing, 27(8), 673-685.

Fafchamps, B., \& Minten, B. (1998). Relationship and traders in Madagascar [Discussion Paper No 23]. Stanford, CA: Department of Economics, Stanford University.

Fafchamps, B., \& Minten, B. (1999). Social capital and the firm: Evidence from agricultural trade. Social Capital Initiative [Working Paper No 17]. Washington, DC: The World Bank.

French, N. (1997). Market information management for better valuations part I: Concepts anddefinitions of price and worth. Journal of Property Valuation and Investment, 15(5), 403-411.

Friedman, M. (1980, February 21). The power of the market. The Listener, 229-231. London: Immediate Media Company London Limited.

Forget, P., Monteiro, T., D'Amours, S., \& Frayre, J.M. (2008). Collaborative agent-based negotiation in supply chain planning using multi-behaviour agents [Working Paper No CIRRELT-2008-54], Québec, Canada: Inter-university Research Centre on Enterprise Networks, Logistics and Transportation (CIRRELT).

Giddens, A. (1984). The constitution of society: The outline of the theory of structuration. Oxford, UK: Polity Press.

Gill, M., \& Turbin, V. (2001). Evaluating realistic evaluation: Evidence from study of CCTV. Crime Prevention Studies, 10, 179-199.

Godes, D., Mayzlin, D., Chen, Y., Das, S., Dellarocas, C., Pfeiffer, B., Libai, B., Sen, S., Shi, M, \&Verlegh, P. (2005). The firm's management of social interactions. Marketing Letters, 16(3/4), 415-428.
Hammervoll, T. (2014). Service provision for co-creation of value: Insights from exchange and production economy perspectives. International Journal of Physical Distribution and Logistics Management, 44(1/2), 155-168.

Heath, R.L., \& Bryant, J. (2012). Human communication theory and research: Concepts, context and challenges (2nd ed.). New York: Routledge.

Jensen, J.D., \& Møller, A.S. (2007). Vertical Price Transmission in the Danish food marketing chain. Copenhagen: Institute of Food and Resource Economics, University of Copenhagen.

Ketoviki, M., \& Choi, T. (2014). Renaissance of case research as a scientific method. Journal of Operations Management, 32(5), 232-240.

Krendl, K.A., Ware, W.H., Reid, K.A., \& Warren, R. (1996). Learning by any other name: Communications research traditions in learning and media. In D.H. Jonassen (Ed.), Handbook of research for educational communications and technology (pp. 93-111). New York: Macmillan.

Lin, N. (2001). Social capital: A theory of social structure and action. London, UK and New York, USA: Cambridge University Press.

Manski, C.F. (2000). Economic analysis of social interactions. The Journal of Economic Perspectives, 14(3), 115-136.

Mankiw, N.G., \& Taylor, M.P. (2014). Economics. London, UK: Cengage Learning.

Healy, T., \& Côté, S. (2001). The well-being of nations: The role of human and social capital. education and skills. Paris, France: Organisation for Economic Cooperation and Development.

Orton, J.D., \& Weick, K.E. (1990). Loosely coupled systems: A re-conceptualization. The Academy of Management Review, 15(2), 203-223.

Pagell, M., \& Wui, Z. (2009). Building a more complete theory of sustainable supply chain management using case studies of 10 exemplars. Journal of Supply Chain Management, 45(2), 37-56.

Pawson, R., \& Tilley, N. (1997). Realistic evaluation. London, UK: Sage.

Penrose, E. (1959). The theory of the growth of the firm. Oxford, UK: Oxford University Press.

Phillips, R., Simsek, A.S., \& van Ryzin, G. (2014). Estimating buyer willingness-to-pay and seller reserve prices from negotiation data and the implications for pricing [Working Paper No 2014-1]. New York: Center for Pricing and Revenue Management, Columbia Business School.

Prashanth, N.S., Marchal, B., Kegels, G., \& Criel, B. (2014). Evaluation of capacity building program of district health managers in India: A contextualized theoretical framework. Front Public Health, 2(89), 1-14.

Salter, K., \& Kothari, A. (2014). Using realist evaluation to open the black box of knowledge translation: A state-of-the-art review. Implementation Science, 9(115), 1-14.

Scheinkman, J.A. (2008). Social interactions. In S. Durlauf, \& L. Blume (Eds.), The new palgrave dictionary of economics (2nd ed.). New York: Palgrave Macmillan. 
Serageldin, I., \& Grootaert, C. (1997). Defining social capital integrating the economist's and the sociologist's perspective. Washington, DC: The World Bank.

Syahyuti, S. (2008). The role of social capital in agricultural trade. Forum Penelitian Agro Ekonomi, 26(1), 32-43.

Sycara, K., \& Dai, T. (2010). Agent reasoning in negotiation. In D.M. Kilgour, \& C. Eden (Eds.), Handbook of Group Decision and Negotiation (pp. 437-451). New York: Springer.

Thompson, J.D. (1967). Organizations in action. New York: McGraw Hill.

Thompson, W.E., \& Hickey, J. V. (2005). Society in focus: An introduction to sociology (5th ed.). Boston, MA: Pearson.

Turner, J.H. (1988). A theory of social interaction. Stanford, California: Stanford University Press.

Vargo, S., \& Lusch, R. (2004). Evolving to a new dominant logic for marketing. Journal of Marketing, 68(1), 1-17.
Vavra, P., \& Goodwin, B.K. (2005). Analysis of price transmission along the food chain [Working Paper No 3], Paris: OECD Publishing.

Wilson, T.D. (1999). Models in information behaviour research. Journal of Documentation, 55(3), 249-270.

World Bank. (2010). Negotiation.Communication for Governance and Accountability Program (CommGAP). Washington, DC: The World Bank.

World Development Report. (2015). Mind, society, and behavior. World Bank Group. Washington, DC: The World Bank.

Yin, R.K. (2013). Case study research, design and method (5th ed.). Thousand Oaks, California: Sage.

Young, H.P. (2007). Social norms [Economics Series Working Paper No 307]. Oxford: University of Oxford, Department of Economics. 